\title{
MADURESE WOMEN AND BINDING CULTURE IN MUNA MASYARI'S MARTABAT KEMATIAN: GYNOCRITICISM ANALYSIS
}

\author{
Erika Citra Sari Hartanto ${ }^{1}$, Miftahur Roifah ${ }^{2}$ \\ English Study Program, Faculty of Social and Cultural Sciences, \\ Universitas Trunojoyo Madura, Madura, Indonesia ${ }^{12}$ \\ erika.hartanto@trunojoyo.ac.id ${ }^{1}$,miftahur.roifah@trunojoyo.ac.id ${ }^{2}$
}

\begin{abstract}
Muna Masyari is a famous female author from Pamekasan, Madura, whose one of her short stories, Sortana, won an award from Kompas, a national newspaper, as the best short story in 2017. Through her short stories, she consistent in depicting the social problems, particularly, related to Madurese women. This article discusses the portrayal of Madurese women in four short stories, namely Kembang Pengantin, Rumah Hantaran, Are' Lancor, and Topeng Gelur. This article focuses on Madurese women as daughter and mother and their relation to nature and oppressed culture. This study uses a descriptive approach with the close reading method. Data collection is in the form of words and the data analysis is done by interpreting the data based on Elaine Showalter's Gynocriticism which concerns women as a writer as well as the producer of literary texts. Gynocriticism mostly deals with four models; they are women's writing and women's body, women's writing, and women's language, women's writing, and women's psyche, and women's writing and women's culture. The results show Masyari reveals many problems attached to Madurese women through women's body, language, psyche, and culture. Madurese early arranged marriage and myths have placed Madurese women in oppressive and unfortunate conditions due to the binding culture that has dominated women. Muna Masyari, yet, places her female characters who are daring to speak their voice to have their own authority in searching for their destiny in the future.
\end{abstract}

Keywords: Gynocriticism; Madurese culture; Madurese women; Muna Masyari

\section{Introduction}

Within a world ruled by patriarchal values, it has been known for decades that women participatory in literature are excluded systematically in the literary canon. Women are denied their access to producing literary texts because they are regarded as incompetent, incapable, and irrational, for they were not able to write as well as men's. Hence, they have to publish their works by pseudonym. In another word, women are expected to, only, be readers instead of the producer of their own narratives. Women should consume male works in which full of bias in depicting women characters because of the patriarchal convention. Women cannot get the real representation of their own since they are described as weak, passive, and irrational.

Elaine Showalter observed that for years women have been oppressed and placed in the second position, not only in the real world but also in literary development. She argued, "Traditionally women have been cast in the supporting 
rather than the starring roles of literary scholarship." (1985, p. 128). It means that in the world of male authority, the role of women is in the periphery rather than in the center. Hence, in her essays, she is concerned much about the way women were articulated in literary works and production. She offered that there are two types of feminist criticism, woman as reader and woman as a writer. In the first type, she called it a feminist critique focusing on the ideological assumptions of literary phenomena. The first type of criticism paid much attention to the portrayal of women in the male-oriented world. As the result, in male literary tradition, women were not supported with adequate and inequity positions or portion. Also, women were given restricted roles and functions since readers were not fulfilled with the thought, feelings, and experiences of women. Otherwise, women were supposed to be and to do become the main concerns within the male critics and tradition. The second type is concerned with a woman as a writer which means that woman is the producer of textual meaning with the history, themes, genres, and structures of literature. In this second type, she coined the term of Gynocritics, adapted from the French term la gynocritique (Showalter, 1985, p. 128). Showalter believed that women can generate their own creativity with a diverse focus to get a better reflection in literary works. Constructing and narrating an ideal female framework becomes one of the main concerns in feminist criticism.

Talking about Indonesian contemporary literature, especially in
Madura, a few names can be mentioned and most of them are male authors, such as KH. D. Zawawi Imron, Abdul Hadi W.M., Jamal D. Rahman, etc. However, young Madurese authors, recently, emerge and get national attention for their works are precious to be analyzed, for example, Royyan Julian, Zainul Muttaqin, Muna Masyari, and Dwi Ratih Damayanti. Among those young Madurese authors, Dwi Ratih Damayanti and Muna Masyari are female Madurese authors who are productive in writing literary works.

Muna Masyari is the pen name of Munawaro, who was born in Pamekasan, Madura, East Java. She has won several awards for her writings. There are several reasons for this study to choose Muna Masyari's work. Firstly, her short stories, Sortana or Kasur Tanah, won an award from Kompas as the best short story in 2017. Secondly, her collection of short stories in Martabat Kematian (2019) can be regarded as a portrayal of Madurese culture. The book consists of a collection of seventeen short stories which have been published in different media, magazine, tabloid, and newspaper, from 2012 until 2018.

Her works is as a voice in depicting Madurese women within patriarchal Madurese society. Talking about Madurese society, it is closely related to how its culture is significantly affected by Islam, as stated by KH. A. Dardiri Zubaidi that Islam in Madura is not only a majority religion but also has already become Madurese identity (2020, p. 6). Thus, patriarchal Madurese culture has greatly been influenced by religious values and beliefs. 
The position of men in Madura is considered higher than Madurese women. As a leader within the family, Madurese men have full authority and power to be responsible for household needs. On another side, Madurese women are regarded as a second class since, after marriage, they will become their husband's responsibility. In this context, thus, it is significant to explore Madurese women, especially Madurese women's portrayal in literary works.

Muna Masyari's short stories consistently depict the voice of Madurese women, in their position as a woman, daughter, mother, and daughter-in-law, related to the patriarchal Madurese society and culture. Their narration, along with the culture exists in Madura, is told splendidly by Muna Masyari using first and second point of view. It means that she, deliberately, inquires her readers to experience themselves the situation of Madurese women in her stories. Hence, it is valuable to analyze her short stories. However, not all of the short stories are chosen as the source of data for this study. This paper examines the portrayal of Madurese women in four short stories included in an anthology of Martabat Kematian by Muna Masyari. Those four short stories are Kembang Pengantin, Rumah Hantaran, Are' Lancor, and Topeng Gelur, because those stories are rich with Madurese culture as well as the problem of Madurese women within a patriarchal society.

For this reason, Gynocriticism appeared to "construct a female framework for the analysis of women's literature, to develop new models based on the study of female experience, rather than to adapt male models and theories" (Showalter, 1985, p. 131). In this context, we can see that women struggle to free themselves from the stereotypes made by a male, free themselves from the male construction of women, and trying hard to build up the new version and image within the female culture. Since gynocritics mainly focus on a woman as a writer, hence, this article will scrutinize four works from Muna Masyari as a female author from Madura, from the perspective of four models of Gynocriticism, they are women's writing and women's body, women's writing and women's language, women's writing and women's psyche and the last is women's body and women's culture.

There have been researches concerning Muna Masyari's works. Some of them see the issue of Madurese cultural identity. Mawardi analyzed four Indonesian short stories, one of them is Muna Masyari's Arek Lancor, focusing on the cultural artifact, such as celurit and lincak, as the trail of colonial culture and Madurese cultural identity (Mawardi, 2016). Other researchers analyzed Muna Masyari's five short stories, "Gentong Tua", "Kemeja Batik", "Bulan Berdarah", "Celurit Warisan", "Kasur Tanah", and "Sumur" focusing on the representation of Madura locality. The result showed that the short stories were dominated by Madura localities: background, economy, language or term, tradition, myth, weapon, and religiosity (Ridwan \& Sayuti, 2020). Other 
researchers analyzed Muna Masyari's Kasur Tanah with emphasis on morality values (Faozi \& Qomariyah, 2020), and on elevating and interpret the tradition of obsequies (Ilma, Bakthawar, \& Pamulang, 2020).

Other researchers have analyzed the portrayal of Madurese women using the feminism approach. The first researchers analyzed Muna Masyari's Sangkar Perkawinan with the result that women's image is manifested in the form of a physical image, psychic, helpless, resigned to the situation, housewife, loyalty, child guard, domestic, husband's companion, and social (Juanda \& Azis, 2018). The second researcher analyzed three short stories by Muna Masyari, they are Dukka Ronjangan, Matinya Damar Kembang, and Sortana, using the feminism approach, particularly gynocriticism. The results showed that among the four models of Gynocritic, Masyari does not exploit the body or biology of women as the source of her writing. Instead, she mostly talks about the psyche of women and language usage, and the narration of Madurese cultures (Roifah \& Hartanto, 2019).

This present study is different from the previous one. Although this study used the same theory, yet, the source of data is different. This present study applies Gynocriticism in four Muna Masyari's short stories, Kembang Pengantin, Rumah Hantaran, Are' Lancor, and Topeng Gelur. Madurese culture of early arranged marriage becomes a prominent topic in several short stories as it is a background of the conflict in determines the female characters' actions, feel, thought, and reactions. The culture is also a source of her main characters' restlessness, henceforth, and articulating their voices.

\section{Research Method}

This research design uses a descriptive approach with the close reading method. Close reading is carried out to understand the core meaning of the story. Data collected in the form of words that is related to the actions and speech of women characters in the research corpus, which is Kembang Pengantin, Rumah Hantaran, Are' Lancor, and Topeng Gelur. After the data is being collected, the researchers verify and eliminate the data which do not correlate with the topic of the study. The analysis of the data is done by interpreting the collected data by the four models of Gynocriticism proposed by Elaine Showalter, which is women's writing and women's body, women's writing, and women's language, women's writing, and women's psyche and the last is women's body and women's culture. Furthermore, to support the data analysis, the data is analyzed by combining the gynocriticism perspective and information about Madurese culture which specifically addresses the early arranged marriage.

\section{Results and Discussion}

This paper scrutinizes the four models of gynocriticism in Muna Masyari's four short stories. The discussion starts with the first model, women's writing and women's body, which is reflected in Are' Lancor and 
Topeng Gulur. The second model, women's writing and women's language is portrayed in Kembang Pengantin and Rumah Hantaran, while that analysis is also considered as a reflection of the third model, women's writing and women's psyche. The last model, women's writing, and women's culture depict the culture or early arranged marriage which presents in Kembang Pengantin and Rumah Hantaran.

\section{Women's writing and women's body}

In the first model, women's writing and woman's body, Showalter pointed out that this model generally stresses the importance of the body as a source of imagery as Showalter showed that contemporary American women poets use a franker and more pervasive anatomical imagery. And the nature of writing is considered intimate, confessional, and often innovative in style and form like. The study of biological imagery in women's writing is useful and important as long as we understand that factors other than anatomy are involved in it. Ideas about the body are fundamental to understanding how women conceptualize their situation in society (1975, pp. 188-189) Hence, the study of women's body is considered precious since it involves women intimate experience with their body. How women describe and portray their experience into writing is also important because only women can experience the journey. The discussion of this first model is depicted in Masyari's short stories entitled Are' Lancor and Topeng Gulur.
Are' lancor is following the story of Sakduh, a young Madurese boy whose father has been arrested by the police while, his mother is a coffee seller. It is told that his mother is still young, beautiful and having a delicate body. Consequently, many men are interested to and often seduce her despite her status as a wife and a mother. To avoid bad men, his mother keeps singing Madurese song or ngejhung (kejhungan) yet it does not stop those men from teasing her. A man was caught in the act of pinching his mother's buttocks and arise Sakduh's father's rage. He killed the man using are' lancor. Are' lancor itself is a famous sharp weapon (celurit) from Madura and it is used as a weapon to injure or kill someone who has humiliated one's honour. While his father is away, Sakduh, as a boy, is the only person who stays beside his mother. The story ends with Sakduh's mother is cornered as there are three bad men who try to approach and seduce her and Sakduh sees her mother's upper clothes has already been torn.

This model depicts a Madurese woman's body as a source of men's pleasure. Those bad men consider Sakduh's mother's delicate body is an object to be gazed by them. They project their sexual desire and fantasy upon her body as shown in the act of seducing by pinching her buttocks. As described by Mulvey, "women have the 'to-be-lookedatness' characteristic. The gaze is directed at the female body, commonly by a male and it actively projects the man's fantasy upon the women's body. Within this relationship, women are both an object to 
be gazed at and a showpiece to be displayed" (Clark, 2017, p. 1).

The act of those bad men doing sexual harassment is a representation on how Madurese men regard their women. Patriarchal culture considers women as submissive and weak, moreover, powerless. In this short story, Muna Masyari portrays a Madurese woman who does not have power in defending her life, whether in private or in public. In private life, she has to rely upon her husband's protection, moreover, in public she has to experience of sexual harassment. The absent of a man's role in protecting and defending the woman make a woman's position becomes much more difficult.

Topeng Gulur tells about dry season in a village in Madura and people try to find the solution in order to the rain falls. The conflict exists because disagreement between main characters and other people in the way to discover the solution. Main characters in the story insist to perform "Topeng Gulur", while the other people want to held sholat istisqa'. Topeng Gulur is considered as a rite of an expression of unification between man and earth. It is functioned as a practice to celebrate and feel grateful to God for the abundance of farm production. It is performed by three people who wear red masks and headband, long black hair made from thread crochet, beaded vest, garlands, and belt and ghungseng ankle bracelet. The dance itself is dominated by the dance movement accompanied by music of gendang, kecrek, and saronen and it is held in Taneyan Lanjheng, a typical of Madura house (Fauzi, 2014, p. 9)
In this short story, male main characters, Munajib, Surakkab, and Muraksah first thought that the dry season because of one of village women is having pre-marital pregnancy. However, they see none of them is pregnant. Therefore, led by Muraksah, they insist to perform Topeng Gulur dance as they think that dry season happens because of the dance is no longer being held since Keh Sakduh, an Islamic leader, prefer to do sholat istisqa. In addition, Munajib wants to propose Marinten, a daughter of Muraksah, for his niece. Hence, he agrees when Muraksah asks him to join in performing Topeng Gulur dance. In the end of the story, readers will find out that Marinten is the one who is in three months pre-marital pregnancy.

In this short story, Masyari reveal how Madurese men's view of Madurese women. They view and connect women's body with nature, in which the balance of life cycle of nature becomes women responsibility. The works of nature is dependent on women's purity as patriarchal beliefs see nature to be defined as "passive, as non-agent and non-subject" (Plumwood, 2016, p. 4). Patriarchal values also define women's virginity and submissive is significant, hence, women who do not accept that kind of values are considered as bad or monstrous women. Patriarchal society positions a woman who is having pre-marital pregnancy is a bad woman because she is not virgin and breaks the purity as well as interrupts the life cycle of nature. As a consequence, nature's work is destroyed and brings 
suffer for people, for example a long dry season happens in the village.

\section{Women's writing and women's language}

In women's writing and women's language, Chantal Chawaf argued that the connection between feminism and linguism is in the view that women's language and a genuinely feminine practice of writing will articulate the body (Showalter, 1975, p. 193). Moreover, Showalter argued that human's language and style are influenced by plenty of aspects, because language and style are always the products of genre, tradition, memory, and context, etc. She believes that feminist criticism function is to concentrate on women's access to language, on the available lexical range from which words can be selected, on the ideological and cultural determinants of expression. The problem is not that language is insufficient to express women's consciousness but that women have been denied the full resources of language and have been forced into silence, euphemism, or circumlocution (1975, p. 193).

This model is portrayed in Muna Masyari's short stories entitled Kembang Pengantin and Rumah Hantaran as the main characters questioning about the prevailing Madurese tradition of early arranged marriage in which Madurese women have to marry in a very young age although they do not fully comprehend their task in becoming wife and mother. These two short stories portray the relation between Madurese mother and daughter. Through the voice of main character, Masyari brings her readers to position themselves in the eye of a Madurese woman who is in problematic situation, yet the main character tries to speak and to break the 'silence' because, as a Madurese woman, she cannot free herself from the demanding and controlling tradition in performing motherhood.

In Kembang Pengantin, the story is narrated by Aspuyeni, the main character, using first point of view. Hence, readers will get complete understanding of her experience, feeling and thoughts. In this story, the main character several times using interrogative question structures, especially when she is dealing with the tradition of early marriage. She questions about the difference attitude experienced by male and female, for example why male is privileged to burst out laughing, instead of women, and why female has to wait for male to propose first, instead of female (Masyari, 2019, pp. 49-52) Her using of interrogative question structures deliver notion that Madurese men are regarded as active, while Madurese women have to be submissive and wait for the men to propose first. Through Aspuyeni character, Muna Masyari questions the discriminating situation and circumstances that Madurese woman has to undergo in determining her fate in the future.

Different from Aspuyeni, her mother often uses imperative structures in her language, for example when she warns and restricts her daughter for not breaking certain norm so that her daughter, soon, 
will get a husband. McConnell-Ginet argued that "the many specific differences in male and female speech, intonation, and language used that have been identified cannot be explained in terms of "two separate sex-specific languages" but need to be considered instead in terms of style, strategies, and contexts of linguistic performance" (Showalter, 1975, p. 193). In the context of Madurese motherhood, Aspuyeni's mother functions as the controller of Madurese tradition who has internalized patriarchal values through her style of language. Masyari, through Aspuyeni's mother, presents another Madurese woman as a person whose main roles is to maintain the prevailing values.

Imperative sentence itself functions as to give command and warning someone and it will bring consequence. Hence, the voice of Aspuyeni's mother can be regarded as giving command and warning her daughter for not breaking the prevailing values and norms in society. If she fails to warn her own daughter, she will be regarded as a failing mother who fails in doing Madurese motherhood. O'Reilly states that "patriarchal motherhood is oppressive to women" (2016, p. 65). Madurese society is influenced much by patriarchy as well as the practice of Madurese motherhood, which is oppressive to women. It is avoidably for Aspuyeni's mother to warn and command her daughter in order to preserve Madurese tradition of early arranged marriage. The question structures used by Aspuyeni and the imperative structures used by Aspuyeni's mother indicate that, both Aspuyeni and her mother function as victims of Madurese culture as they cannot free themselves from the values. Masyari creates Madurese women as victim of patriarchal society in which women have to follow the order in society.

In Rumah Hantaran, Masyari uses second point of view in narrating her story. The usage of second point of view is the calling of Masyari to her readers for she has special purpose. It tells "You" as the main character who marries in a very young age. She is described as a naïve and inexperienced girl for she marries at the age of fourteen. Her husband works in a remote country and gives her a house as her dowry.

The house is described as a fine house made from fine woods and completed by three pillars. Her mother explains the meaning of those pillars is related to honesty, faithfulness, and sincerity to the values of marriage. She explains that a mosquito net is not only functioning as a net to keep the mosquitoes away, but also symbolising the satire of life. It means that husband and wife should keep their household's problem secretly and get together in overcoming the problem, unless they need trustworthy parents or person to help them. And, the mother of "You" character says that as a wife, as long as she lives in that dowry house, her love and faithfulness are the one at stake (Masyari, 2019, pp. 57-58). As a young bride, she accepts those values of marriage symbolised by the house.

Those values itself can be regarded as doctrines from Madurese mothers to their daughter. Those embedded doctrine 
has confined many women since they are expected to be good wives in the eye of husband, in-law and society. As the story goes, she finds out that her husband is doing infidelity. The story reveals main character who expresses her feeling using interrogative questions related to her husband's deed and her future life (Masyari, 2019, pp. 60-63). She, then, realizes that the fine house as her dowry is not a symbol of prosperity or woman's glory, but it is a symbol of confinement which imprisons Madurese women by status.

However, by delivering critics through question structures, it can be indicated that Aspuyeni and "You" characters resist the culture which put them into unfortunate situation for they do not have their independent of their own life. Their resistance over Madurese culture is highlighted by Masyari as the stories' plot reach its end. Kembang Pengantin depicts Aspuyeni as a Madurese woman who marries late in the age of 37 and she is the one who proposes a man as her husband. Masyari describes the main character who builds her self-awareness as well as self-confidence in doing such deed. While in Rumah Hantaran, Masyari depicts the character of "You" that resists the culture of restricting Madurese women's right in her act of destroying the pillars of her house. Her deed indicates that she breaks those pillars as a symbol of a woman's independency and bravery. Masyari portrays "You" character's language who uses exclamation marks in her sentences (2019, p. 63) which indicates her protest and resistance.

\section{Women's writing and women's psyche}

The third model, women's writing and women's psyche focuses on feminist psychoanalysis for literary criticism which differentiate the process of women's writing in the author's psyche and in the relation of gender to the creative process. It means that psychological condition of women author and women's relation of gender have contributed much on the creative process of women's text and product. In addition, Showalter pointed out that the relation of between mother and daughter can be regarded as a main source in writing text (1975, p. 196).

This model is portrayed in Kembang Pengantin and Rumah Hantaran. In this model, Masyari depicts how Madurese main characters' psyche in relation to Madurese culture. The psychological condition of Masyari's main characters is revealed through the language they use in facing the culture of arranged marriage. Madurese women are in unfortunate condition because they do not have power and higher position to decline the marriage proposal. In addition, Madurese parents even married off their daughter in their very young age.

Early marriage still occurs on Madura Island because Madurese "communities still hold a matchmaking (pajhudan) tradition. Rahmad said that the truth of early marriage is considered as a form of moral embodiment of Islamic Madurese 
society and a cultural agreement in Madurese society. Therefore, early marriage can be a cultural relativism of the Madurese community" (Bawono \& Suryanto, 2019, pp. 86-87). However, a research of the impact of early marriage in Larangan Luar village, Pamekasan regency by Bawono and Suryanto, showed that not all Madurese women who were married in a young age feel in difficult situation, moreover, they can achieve happiness afterward (2019, p. 85). It is different from Madurese women portrayed by Masyari in her stories.

In the previous model, it is showed that the character of Aspuyeni and "You" use question structures which also indicate the psyche of Madurese women. Masyari lives in the midst of culture of early arranged marriage in Madura, hence, she is completely understood the inner feeling and thought of Madurese women who cannot break or even have power to reject the culture. They are facing difficult and problematic situation for they are not considered as women who have rights to decide their own life, yet, their male elders do. Through her language usage, Masyari shows her reader that her female characters do not have power to negotiate their position within family. Their questions critic the prevailing Madurese patriarchal culture in which Madurese male is regarded as having higher position and power than female.

"Rumah Hantaran" depicts "You" character who voices her inner feeling using questions structures and exclamation mark which indicates her psyche in dealing with her problem. She says,

"Jujur, setia, menerima!
Inikah pilar kejujuran yang
akan terus menopang sangkar
perkawinan?

Tidak! Kejujuran itu terakui setelah terjadi pengkhianatan.

Kesetiaan sesuci apakah yang harus dipertaruhkan?" (Masyari, 2019, p. 63)

The quotation implies that she feels anger, bitterness, and disappointment toward her husband. Further, it can be regarded that she addresses her devastated feeling to her culture as it claims that a Madurese woman should obey and faithful to her husband. Moreover, she should be able to cover her husband's weakness and mistake, although her husband treats her badly by doing adultery. At the end of the story, she holds a kind of sharp weapon in order to destroy the pillars of the house as symbol for seeking freedom of herself. Through the language usage in this short story and her act of breaking the pillars, Masyari shows her readers that a Madurese woman also has the right in demanding her authority in pursuing her life in the future. A Madurese woman cannot always be passive because she has her dependency and willingness in deciding what is best for her. This indicates that Madurese women have to take action to take control of their own lives. She is free to choose her own fate and not dependent on other people in deciding their life and future. 


\section{Women's writing and women's culture}

The last model, women's writing and women's culture, Showalter argued that women's culture as main source for women to construct and conceptualize their bodies and their sexual and reproductive functions. Women's live consists of women's role, activities, daily habit, tastes and behaviours for those values result myriad experience. (1975, pp. 197-198). It is meant that women's live and how they relate their live into environment and her surrounding as a major foundation in women creative process.

This analysis provides the culture and tradition that binds Madurese women, that is early arranged marriage. Muna Masyari is a Madurese woman who was born and is still living in Madura. Hence, she is strongly familiar with Madurese culture as well as the cultural life of Madurese women, especially in Pamekasan. This culture is a common practice in four regions in Madura and it is still practicing until today. In short stories titled Kembang Pengantin and Rumah Hantaran, Masyari depicts the main characters, Aspuyeni and "You", that are faced and forced to marry in a young age. Another issue that she explores is the myths surround Madurese girls.

Report says that "Indonesia ranks 37 of the countries in the world with the highest rate of early marriage. Center for Gender and Sexuality Studies, University of Indonesia reported in 2015 that Indonesia rank the second highest rate of early marriage in South East Asia" (Wijayati, Soemanto, \& Pamungkasari, 2017, p. 302). Furthermore, Wijayanti et al pointed out that several factors influence the occurrence of early marriage such as knowledge, belief, culture, education, income and peers (2017, p. 303).

In Madura, Wiyata (2015) argues, the culture of early arranged marriage is common among Madurese in order to maintain the family's honour from the feeling of disgrace and shame if their daughter has not yet married. A Madurese woman will marry as soon as she gets her first period, at the age of 12 until 15 years old (in Rofika \& Hariastuti, 2020, p. 14). Moreover, Sya'dan adds that in some areas in Madura, there is tradition where the families engage their children even when the baby is still in womb (2015a, p. 145). There are some reasons for this culture and tradition to be existed, even until today. Among those reasons are to maintain the family's lineage, low economy and education, pressure from parents and children's obedience, pre-marital pregnancy, trust in religious leaders, and myth about being an old maid (see Jamilah, 2019; Jannah, 2011; Munawara, Yasak, \& Dewi., 2015; Rofika \& Hariastuti, 2020; Sa'dan, 2015a, 2015b; Suyono, 2018).

Related to the influence of religious leaders over early arranged marriage, Suyono explains more that the existence of early arranged marriage in Madura cannot be removed from religious leaders' guidance, such as Mak Kaeh (Kiai or Ulama), Pangaseppo (respected person), and Bendoro/Lora (son of Kyai). Madurese 
people still hold firmly (2018). He argues, the local people are still upholding the customs derived from Islamic cultural teachings. This is possible due to strong influence of pesantren education that grows and develops in the village. This "santri" culture then confirmed the strong role of clerics and community leaders, as a form of their obedience. So that the norms of life for the people in this village are dominated by the actions or speeches shown by the leaders" (2018, pp. 198-199).

Another thing that is also important to be highlighted is the myths' existence around the girls within Madurese society and it is passed down from generations. The myths mainly relate to the house chores, the things that Madurese woman should not do, such as it is prohibited to a woman sitting in front of the house's door. It is prohibited to a woman for being lazy since it is bad in the eye of mother in-law. It is also prohibited to eat sangkal banana due to bad luck. It can make a Madurese woman becomes an old maid (Masyari, 2019, p. 49). Sangkal banana refers to banana fringe since the typical of banana fringe is it has 3 parts (geligir) while other banana has 4-5 parts. The myth is if a Madurese maiden eats banana fringe, no man will purpose and marry her ("Beragam Mitos Bagi Anak Perawan Madura,” 2017). Furthermore, according to Mutmainnah, sangkal means a bad action or saying which gives bad impact for the person who does it. Within Madurese society, the belief of sangkal is still present until today. When someone breaks it, sanction will come upon the person (2018, pp. 1-2).
Therefore, the myths 'force' the parents to obey, if not, they will get something bad, for example they will be humiliated by the society. it is common to find Madurese parents feel worry about finding future husbands for their daughters. The daughters should marry as early as possible for their parents are afraid if their daughter(s) do not get husband (Zubaidi \& Zainol, 2019). It is a shame for having daughters who are late in getting married. Neighbours will gossip over the family and the daughter will be bad example and be called unfortunate old maiden. In this context, the myths can be considered as controlling rules in defining Madurese women's identity. Being a 'true' Madurese woman means Madurese woman who marries in early age, who is not sitting in front of the door, and who is working diligently, even early in the morning in order to please their mother in law and who obey what the parents ask her to do.

Hence, Masyari has constructed the culture of Madurese people as a source of creative process in her short stories. Masyari describes Madurese culture of early marriage as a set of rules and tradition surround the life of Madurese women. In another words, Madurese women are expected to live and constructed as told by the culture. Madurese women, still, cannot be free from tradition and rules that bind them which regard women as having inferior position. It is avoidably that Madurese women' live are determined by other people, in this case is the elders family and society. 


\section{Conclusion}

The four short stories of Muna Masyari have portrayed Madurese women by four models of Gynocriticism. Masyari has told the readers many problems attached to Madurese women and it is revealed through their body, language, psyche, and culture. Masyari depicts Madures women's body associated with nature and a site of men's desire. The language they use represents their question and reflection upon their life and it mirrors their psyche. The culture of early arranged marriage has become barrier in women's development and advancement. Madurese women are described as being oppressed by the culture because not only male but also Madurese women maintain the order in society.

On the other hand, even though the female characters are bound with the culture and tradition, yet, Masyari represents them who are brave in taking action and struggling to find their own destiny despite the high risks they have to take. They are eager to question their life to find their own ways to pursue their dream. It means that Masyari places her female characters that can do resistance to the binding culture.

\section{References}

Bawono, Y., \& Suryanto, S. (2019). Does Early Marriage Make Women Happy?: A Phenomenological Finding from Madurese Women. Journal of Educational, Health and Community
Also, it is strongly encouraged to do another study discussing other potential perspectives and approaches to enrich the findings and results comprehensively. From this short stories collection by Muna Masyari, other interesting issues that are likely to achieve and to research further are the position and role of Madurese father/husband/son within Madurese family, Madurese mother/daughter in performing motherhood/daughterhood, and the construction of Madurese traditional and kinship system. Hopefully, more comprehensive and myriad studies about Madurese writers and cultures can be developed and achieved.

\section{Acknowledgement}

This research article is sponsored and fully funded by LPPM Universitas Trunojoyo Madura.

Psychology, 8(1), 85-100. https://doi.org/10.12928/jehcp.v8i1.1 2197

Beragam Mitos Bagi Anak Perawan Madura. (2017). Retrieved August 12, 2020, from www.emadura.com website: 
https://www.emadura.com/2017/11/b eragam-mitos-bagi-anak-perawanmadura.html

Clark, A. (2017). Exploring Women's Embodied Experiences of "The Gaze" in a Mix-Gendered UK Gym. Societies, $8(1)$, 2. https://doi.org/10.3390/soc8010002

Faozi, R., \& Qomariyah, U. (2020). Nilai Moral Pada Antologi Cerpen Kasur Tanah (Cerpen Pilihan Kompas 2017) Dan Kelayakannya Sebagai Bahan Ajar Sastra Di Sma/Ma. Jurnal Pendidikan Bahasa Dan Sastra Indonesia, 9(1), 49-57. https://doi.org/10.15294/jpbsi.v9i1.32 050

Fauzi, M. (2014). Nalar Tradisi Sebagai Strategi Pengembangan Budaya Madura ke Depan (pp. 1-13). pp. 113. Retrieved from https://repository.stkippgrisumenep.a c.id/391/1/nalar tradisi sebagai strategi mengembangkan budaya madura ke depan .pdf

Ilma, A. A., Bakthawar, P., \& Pamulang, U. (2020). Memaknai upacara kematian dalam bingkai lokalitas budaya indonesia: studi kasus tiga cerpen pilihan. SULUK, 2, 14-22.

Jamilah, R. (2019). FENOMENA PERNIKAHAN ANAK DI SUMENEP MADURA. Jurnal Harkat: Media Komunikasi Gender, 15(1), 35-39. https://doi.org/https://doi.org/10.1540 8/harkat.v15i1.13437

Jannah, F. (2011). Pernikahan Dini Dalam Pandangan Masyarakat Madura (Studi Fenomenologi Di Desa Pandan Kecamatan Galis Kabupaten Pamekasan) (Universitas Islam Negeri Maulana Malik Ibrahim Malang). Retrieved from http://etheses.uin-malang.ac.id/2535/ Juanda, J., \& Azis, A. (2018). Penyingkapan Citra Perempuan Cerpen Media Indonesia: Kajian Feminisme. LINGUA: Journal of
Language, Literature and Teaching, 15(2), 71. https://doi.org/10.30957/lingua.v15i2. 478

Masyari, M. (2019). Martabat Kematian (1st editio). Yogyakarta: Sulur.

Mawardi. (2016). Identitas Budaya Madura dalam Cerpen Indonesia (Universitas Negeri Yogyakarta). Retrieved from http://eprints.uny.ac.id/37744/1/Maw ardi 11210141015.pdf

Munawara, Yasak, E. M., \& Dewi., S. I. (2015). Budaya Pernikahan Dini Terhadap Kesetaraan Gender Masyarakat Madura. Jurnal Ilmu Sosial Dan Ilmu Politik Universitas Tribhuwana Tunggadewi, 4(3), 424455.

Mutmainnah. (2018). Persepsi Masyarakat tentang Mitos Sangkal Perempuan Penolak Lamaran di Desa Penagan Sumenep Madura. Pamator, 11(1), 19. Retrieved from http://journal.trunojoyo.ac.id/pamator

O'Reilly, A. (2016). We Need to Talk about Patriarchal Motherhood: Essentialization, Naturalization and Idealization in Lionel Shriver's We Need to Talk about Kevin. Journal of the Motherhood Initiative for Research and Community Involvement, 7(Mother, Mothering and Motherhood in Literature), 64-81. Retrieved from http://journalofmotherhoodinitiative.o $\mathrm{rg} /$ product/mothers-mothering-andmotherhood-in-literature/

Plumwood, V. (2016). Feminism and the mastery of nature. In Ideals and Ideologies: A Reader. https://doi.org/10.4324/97813156255 46

Ridwan, \& Sayuti, S. A. (2020). Madura Locality in Muna Masyari's Short Stories. 461(Icllae 2019), 412-416. https://doi.org/10.2991/assehr.k.2008 04.081

Rofika, A. M., \& Hariastuti, I. (2020). Social-Cultural Factors Affecting Child Marriage in Sumenep. Jurnal 
PROMKES, $\quad 8(1), \quad 12$. https://doi.org/10.20473/jpk.v8.i1.202 0.12-20

Roifah, M., \& Hartanto, E. C. S. (2019). The Portrayal of Madurese Women in Muna Masyari's Short Stories: "Dukka Ronjangan," "Matinya Damar Kembang," and "Sortana." In Bramantio, A. Setijowati, \& T. D. Soelistyarini (Eds.), SASTRA, BUDAYA, POLITIK, DAN KEBANGSAAN Prosiding Seminar Nasional Hiski Komisariat Surabaya (pp. 66-72). Surabaya: Fakultas Ilmu Budaya Universitas Airlangga.

Sa'dan, M. (2015a). Menakar Tradisi Kawin Paksa Di Madura Dengan Barometer Ham. Musãwa Jurnal Studi Gender Dan Islam, 14(2), 143. https://doi.org/10.14421/musawa.201 5.142.143-156

Sa'dan, M. (2015b). Tradition of ForcedMarriage in Madura: a Perspective of Socio-Legal Feminism. Jurnal Perempuan, 20(1), 35-42. https://doi.org/http://dx.doi.org/10.34 309/jp.v20i1.52

Showalter, E. (1975). Feminist Criticism in the Wilderness. 22-41.

Showalter, E. (1985). Toward a Feminist
Poetics. In E. Showalter (Ed.), The New Feminist Criticism: Essays on Women, Literature, and Theory. Pantheon Books, New York.

Suyono, S. (2018). Kredibilitas Pemuka Pendapat Dalam Tradisi Pernikahan Di Bawah Umur (Pernikahan Dini) Di Madura. Mediakom, 1(2), 192-211. https://doi.org/10.32528/mdk.v1i2.15 78

Wijayati, N. A., Soemanto, R., \& Pamungkasari, E. P. (2017). Socioeconomic and Cultural Determinants of Early Marriage in Ngawi, East Java: Application of PRECEDE-PROCEED Model. Journal of Health Promotion and Behavior, 2(4), 302-312. https://doi.org/10.26911/thejhpb.2016 .02.04.02

Zubaidi, \& Zainol. (2019). Kasus Pernikahan Dini Masih Marak di Pamekasan. Retrieved November 6, 2019, from https://mediamadura.com/2019/02/22/ kasus-pernikahan-dini-masih-marakdi-pamekasan/

Zubairi, A. D. (2020). Wajah Islam Madura. Cengkareng, Jakarta Barat: TareBooks. 